\title{
Ticks on birds in a forest fragment of Brazilian cerrado (savanna) in the municipality of Uberlândia, State of Minas Gerais, Brazil
}

\author{
Carrapatos de aves em um fragmento florestal de Cerrado, município de Uberlândia, \\ Estado de Minas Gerais, Brasil
}

Graziela Virginia Tolesano-Pascoli ${ }^{1,2 *}$; Khelma Torga ${ }^{1,2}$; Alexandre Gabriel Franchin ${ }^{1}$; Maria Ogrzewalska ${ }^{3}$; Monize Gerardi²; Maria Marlene Martins Olegário²; Marcelo Bahia Labruna³; Matias Pablo Juan Szabó ${ }^{2}$ Oswaldo Marçal Júnior ${ }^{1}$

${ }^{1}$ Laboratório de Ornitologia e Bioacústica, Instituto de Biologia, Universidade Federal de Uberlândia - UFU

${ }^{2}$ Laboratório de Ixodologia, Faculdade de Medicina Veterinária, Universidade Federal de Uberlândia - UFU

${ }^{3}$ Departamento de Medicina Veterinária Preventiva e Saúde Animal, Faculdade de Medicina Veterinária e Zootecnia, Universidade de Sáo Paulo - USP

Received August 24, 2010

Accepted October 5, 2010

\begin{abstract}
This is a report of ticks species, parasite prevalence and infestation intensity of birds in a forest fragment $\left(18^{\circ} 56^{\prime} 57^{\prime \prime} \mathrm{S}\right.$ and $48^{\circ} 12^{\prime} 14^{\prime \prime} \mathrm{W}$ ) within the Brazilian cerrado (savanna), in the municipality of Uberlândia, State of Minas Gerais, Brazil. A total of 162 birds from 26 species were captured. One adult tick, 296 larvae and 67 nymphs were found on passerine birds. Of these, it was identified 31 larvae and 27 nymphs of Amblyomma longirostre, 17 nymphs of $A$. nodosum, one A. cajennense larvae and one male of Rhipicephalus sanguineus. All other ticks were identified as Amblyomma sp. larvae $(\mathrm{n}=264)$ or nymphs $(\mathrm{n}=26)$. Overall tick infestation intensity and prevalence were 4.32 ticks/infested bird and $52 \%$, respectively. Sampling of host-seeking ticks on the ground within the forest during a two-year period showed only five Amblyomma sp. nymphs and one adult male of $A$. nodosum whereas a search for ticks on domestic animals (cattle, horses and dogs) found Rhipicephalus (Boophilus) microplus ticks. Although identification was possible in only $27 \%$ of bird ticks there seemed to be no correlation between environmental and domestic animal and bird infestation. It can be assumed that bird infestation may occur above the ground or at specific sites not sampled.
\end{abstract}

Keywords: Bird, tick, Ixodidae, Brazilian savanna.

\section{Resumo}

Neste trabalho, são apresentadas as espécies de carrapatos em aves silvestres, sua prevalência e a intensidade de infestação em um fragmento florestal ( $18^{\circ} 56^{\prime} 57^{\prime \prime} \mathrm{S}$ e $48^{\circ} 12^{\prime}$ 14” W) do Cerrado, no município de Uberlândia, Estado de Minas Gerais. Foram capturadas 162 aves de 26 espécies, mas apenas as aves Passeriformes estavam infestadas. Nestas, foram encontrados um carrapato adulto, 67 ninfas e 296 larvas. Dentre os carrapatos foi possível a identificação de 31 larvas e 27 ninfas de Amblyomma longirostre, 17 ninfas de $A$. nodosum, uma larva de $A$. cajennense e um Rhipicephalus sanguineus macho. Todos os outros carrapatos foram classificados como larvas $(\mathrm{n}=264)$ ou ninfas ( $\mathrm{n}=26)$ de Amblyomma sp. A intensidade de infestação e a prevalência de carrapatos foram de 4,32 carrapatos/ave infestada e $52 \%$, respectivamente. Na pesquisa de carrapatos em vida livre sobre a vegetaçáo do fragmento florestal, foram capturados apenas cinco ninfas de Amblyomma sp. e um macho adulto de $A$. nodosum, por um período de dois anos. Carrapatos da espécie Rhipicephalus (Boophilus) microplus foram encontrados parasitando bovinos, cavalos e cáes domésticos da região. Mesmo considerando a identificação de apenas $27 \%$ dos carrapatos das aves, parece não haver correlação entre infestação ambiental, nos animais domésticos, com a infestação das aves. Pode-se supor que a infestação das aves ocorra acima do solo ou em locais específicos não pesquisados neste trabalho.

Palavras-chave: Ave, carrapato, Ixodidae, cerrado.

${ }^{*}$ Corresponding author: Graziela Virginia Tolesano-Pascoli

Laboratório de Ixodologia, Universidade Federal de Uberlândia - UFU,

Av. Pará, 1720, Campus Umuarama, Bloco 2T, CEP 38400-902,

Uberlândia - MG, Brazil;

e-mail: grazielapascoli@yahoo.com.br 


\section{Introduction}

Ticks are major vectors of several infectious diseases for domestic and wild animals as well as for humans. Tick mobility is very restricted and these parasites rely on hosts for their dispersal. Birds are undoubtedly among a tick host with the highest mobility and thus may be regarded as with the highest potential for tick as well as tick-borne disease dispersal. Information on bird ticks in Brazil is scarce and there is no basic information about tick species harbored by each bird species. There are a few reports and more recently, a few systematic studies involving both host species and ecological data but they are restricted to parks in South Brazil or Atlantic rainforest (ARZUA; BARROS-BATTESTI, 2003; ARZUA et al., 2003; MARINI et al., 1996; LABRUNA et al., 2007; OGRZEWALSKA, 2009; OGRZEWALSKA et al., 2008, 2009). The second largest biome in Brazil, the "cerrado" (savanna), has been neglected in this regard.

The cerrado biome of tropical South America covers about 2 million $\mathrm{km}^{2}$, representing about $22 \%$ of the land surface of Brazil, plus small areas in eastern Bolivia and northwestern Paraguay (OLIVEIRA-FILHO; RATTER, 2002). This biome is characterized by an extremely variable physiognomy, ranging from open grassland to forest with discontinuous grass layer. Between these two extremes lies a continuum of savanna formations spanning the entire range of woody plant density, collectively referred as "cerrado" (OLIVEIRA-FILHO; MARQUIS, 2002). The Brazilian cerrado is particularly threatened and has been largely replaced by agricultural activities. Little is known about ticks from this biome (SZABÓ et al., 2007; VERONEZ et al., 2010). At the same time small natural areas are increasingly being protected and preserved, increasing the likelihood of mixing parasites from rural, urban and wildlife areas with unpredictable outcomes. In this context birds might link patches of preserved areas and play a role in tick dispersal. This is a report of tick species on birds, environment and domestic animals in a small forest fragment in the Brazilian cerrado biome.

\section{Material and Methods}

Bird Capture and Location: Birds were captured in a semideciduous forest patch (35 hectares), in a farm (Fazenda Experimental do Glória $-18^{\circ} 56^{\prime} 57^{\prime \prime} \mathrm{S}$ and $\left.48^{\circ} 12^{\prime} 14^{\prime \prime} \mathrm{W}\right)$, belonging to the Universidade Federal de Uberlândia (UFU) in the municipality of Uberlândia, State of Minas Gerais, Southeastern Brazil. Bird capture was performed monthly from March to June 2005. Each time 20 mist-nets along a $300 \mathrm{~m}$ path were used totaling 2000 net-hours. Captured birds were identified (according to RIDGELY; TUDOR, 1989, 1994; SIGRIST, 2006), classified (according to COMITÊ BRASILEIRO DE REGISTROS ORNITOLÓGICOS, 2009), weighed, measured and received metallic bands supplied by the Centro Nacional de Pesquisa para Conservação de Aves Silvestres, Instituto Chico Mendes de Conservação da Biodiversidade (CEMAVE/ICMBIO). All birds were carefully visually examined for ticks. Any tick found attached to a bird was removed with a forceps. Birds were then released.

Host-seeking tick sampling: To establish a possible association between ticks found on birds and those host-seeking in the environment, tick samples from the forest fragment were collected. For tick sampling $\mathrm{CO}_{2}$ traps and cloth dragging were used as described before (SZABÓ et al., 2007) on four different spots eight times for two consecutive years (November 2006 to December 2008) every season with the exception of the winter of 2007. Sampling of each spot was carried out by two researchers using five $\mathrm{CO}_{2}$ traps and dragging them around for approximately $200 \mathrm{~m}$. Cloth dragging was also performed at the borders of the forest fragment under the shadow of trees but outside the forest and the surrounding fence.

Ticks on domestic animals: cattle, dogs and horses from the farm were examined for ticks during the winter and spring 2008. High infestation of bovines precluded collection of all ticks thus only samples were collected.

Tick taxonomic identification: During the present study, we could not perform proper morphological taxonomic identification of immature stages of most Amblyomma species from Brazil. Thus, larvae and nymphs were brought alive to the laboratory, where attempts to rear them to the adult stage were performed by feeding them on tick-bite naïve rabbits, as previously described (LABRUNA et al., 2002). Adults obtained from engorged nymphs were used for species identification of former immature ticks. Larvae from each cluster were reared together to the adult stage to obtain the largest possible number of adult specimens. The taxonomic identification of these adults considered the species of the former larval cluster. Adult ticks were identified by using the taxonomic keys proposed by Onófrio et al. (2006a, b). Rhipicephalus (Boophilus) microplus larvae were identified according to Cooley (1946).

Larvae and nymphs that died in the laboratory before reaching the adult stage were preserved in absolute isopropanol and attempts to identify them were performed by molecular methods as previously described (OGRZEWALSKA et al., 2009). Briefly, a portion of $16 \mathrm{~S}$ rDNA gene was DNA-sequenced and compared to available corresponding sequences generated from adult specimens of Amblyomma species from neotropical areas. Sequence matches $>99 \%$ were considered conspecific.

Voucher tick specimens collected during this study have been deposited in the FAMEV/UFU Tick Collection, Universidade Federal de Uberlândia (accession number: 241.305.542-545).

Data analysis: Overall tick infestation prevalence (percentage of infested hosts) and intensity (total number of ticks/number of infested birds) were calculated as well as for each bird species.

\section{Results}

A total of 162 birds from 26 species (four orders, 10 families and 22 genera) were captured. Most species and individuals were essentially forestal birds ( $\mathrm{n}=24$ species, $160 \mathrm{birds}$ ). Half of the captured bird species were insectivorous $(\mathrm{n}=13)$. Even though most of the captured individual birds were frugivorous $(n=63)$, they were represented by only one species, Antilophia galeata (Pipridae), an endemic bird in the Brazilian cerrado. Synallaxis scutatus (Furnariidae), Platyrinchus mystaceus, Lathrotriccus euleri (Tyrannidae), Turdus rufiventris (Turdidae), Volatinia jacarina (Emberizidae) and Saltator similis (Thraupidae) were passeriform 
species without ticks. Only six birds from five species - Columbina squammata (Columbidae), Phaethornis pretrei, Chlorostilbon lucidus, Thalurania furcata (Trochilidae) and Galbula ruficauda (Galbulidae) - were not passeriform and none of them had ticks.

The most numerous species captured were passeriform Antilophia galeata ( $\mathrm{n}=63)$, Eucometis penicillata (Thraupidae) $(\mathrm{n}=12)$ and Arremon flavirostris (Emberizidae) $(\mathrm{n}=11)$. One adult tick, 296 larvae and 67 nymphs were found on passerine birds (Table 1). Of these, it was possible to identify 31 larvae and 27 nymphs of Amblyomma longirostre (Koch, 1844), 17 nymphs of $A$. nodosum (Neumann, 1899), one $A$. cajennense (Fabricius, 1787) larva, and one male Rhipicephalus sanguineus (Latreille, 1806) (Table 1 ). This $R$. sanguineus specimen was previously reported elsewhere (SZABÓ et al., 2008). All other ticks were identified as Amblyomma sp. larvae ( $\mathrm{n}=264)$ or nymphs $(\mathrm{n}=26)$. Overall tick infestation intensity and prevalence were 4.32 ticks/infested bird and 52\%, respectively. Considering only passeriform birds, infestation intensity and prevalence were 4.32 and $54 \%$, respectively.

Among bird species with more than 5 individuals captured, the highest infestation prevalence was found on Eucometis penicillata (83\%), Saltator maximus (Thraupidae) (80\%), Leptopogon amaurocephalus (Tyrannidae) (75\%) and Basileuterus leucophrys (Parulidae) (63\%) (Table 1). Tick attachment sites were very similar with most (95.8\%) of the larvae found on the eyelids whereas the majority of nymphs $(92.4 \%)$ were found on bird necks.

Only one and four nymphs Amblyomma sp were captured by using $\mathrm{CO}_{2}$ traps in the spring of 2007 and winter of 2008, respectively, and one male $A$. nodosum in the summer of 2007. Dragging by the forest borders on the grass yielded several Rhipicephalus (Boophilus) microplus larvae on most occasions. Of 20 cattle, 14 horses and 11 dogs examined, 11 cattle and 5 horses were infested solely with $R$. (B.) microplus ticks.
Among all ticks captured in the present study, all larvae and three nymphs (two $A$. nodosum and one $A$. longirostre) were identified to species by molecular methods. The remaining ticks were identified by morphology only.

\section{Discussion}

Four tick species were identified from birds in the forest patch format the study site. Among these, there were a single A. cajennense larvae and a single $R$. sanguineus adult. There are several previous records of $A$. cajennense immature ticks on birds but Labruna et al. (2007) highlighted that these reports require further evaluation since larvae and nymphs were not identified by current reliable methods for this species (i.e. rearing ticks to the adult stage or by molecular methods). Records using appropriate identification showed $A$. cajennense nymphs on passerine birds in Atlantic rainforest fragments but in very small numbers (OGRZEWALSKA et al., 2009) or either they were not found at all (OGRZEWALSKA et al., 2008). This is a relevant finding since $A$. cajennense is a major known vector of Rocky Mountain spotted fever agent, Rickettsia rickettsii (LABRUNA, 2009), in Brazil and is the host-seeking tick significantly captured in the cerrado biome (SZABÓ et al., 2007; VERONEZ et al., 2010). At the same time the finding of an adult $R$. sanguineus, a dog tick, on $C$. flaveola was unexpected, probably accidental, but it warrants future awareness (SZABÓ et al., 2008) as this species is of paramount importance due to its ability to transmit major pathogenic agents, such Ehrliquia canis, to its hosts (MACHADO, 2004).

Amblyomma longirostre, a neotropical tick species, is widely distributed throughout South and Central America (GUGLIELMONE et al., 2003) and was the most numerous one found on passerine birds in this study. The highest prevalence of this

Table 1. Ticks found on passerine birds in a semideciduous forest patch of the Brazilian cerrado (18 56 $57^{\prime \prime} \mathrm{S}$ and $\left.48^{\circ} 12^{\prime} 14^{\prime \prime} \mathrm{W}\right)$ in the municipality of Uberlândia, State of Minas Gerais, Southeastern Brazil, 2005.

\begin{tabular}{|c|c|c|c|c|c|c|c|}
\hline \multirow[t]{2}{*}{ Bird family } & \multirow{2}{*}{$\begin{array}{l}\text { Bird species ( } \mathrm{n}^{\circ} \text { of birds } \\
\text { examined/infested birds) }\end{array}$} & \multirow{2}{*}{$\begin{array}{l}\text { Occurrence of ticks } \\
\text { total number }(\%)\end{array}$} & \multicolumn{2}{|c|}{ No of ticks } & \multicolumn{3}{|c|}{ No of ticks identified } \\
\hline & & & larvae & nymphs & A. longirostre & A. nodosum & A. cajennense \\
\hline Thamnophilidae & Thamnophilus caerulescens (4/2) & $38(10.44)$ & 27 & 11 & 4 & 1 & 0 \\
\hline Thamnophilidae & Herpsilochmus longirostris (2/1) & $3(0.82)$ & 2 & 1 & 0 & 0 & 1 \\
\hline Furnariidae & Hylocryptus rectirostris $(6 / 3)$ & $5(1.37)$ & 5 & 0 & 0 & 0 & 0 \\
\hline Tyrannidae & Leptopogon amaurocephalus (4/3) & $9(2.47)$ & 8 & 1 & 4 & 0 & 0 \\
\hline Tyrannidae & Tolmomyias sulphurescens (4/2) & $2(0.55)$ & 2 & 0 & 0 & 0 & 0 \\
\hline Pipridae & Antilophia galeata (63/38) & $191(52.47)$ & 182 & 9 & 27 & 0 & 0 \\
\hline Troglodytidae & Cantorchilus leucotis (3/1) & $6(1.65)$ & 1 & 5 & 2 & 2 & 0 \\
\hline Turdidae & Turdus leucomelas (7/2) & $3(0.82)$ & 0 & 3 & 1 & 2 & 0 \\
\hline Emberizidae & Arremon flavirostris (11/5) & $14(3.85)$ & 5 & 9 & 1 & 4 & 0 \\
\hline Parulidae & Basileuterus flaveolus (5/3) & $3(0.82)$ & 0 & 3 & 2 & 1 & 0 \\
\hline Parulidae & Basileuterus hypoleucus (6/2) & $3(0.82)$ & 3 & 0 & 1 & 0 & 0 \\
\hline Parulidae & Basileuterus leucophrys (7/5) & $23(6.32)$ & 15 & 8 & 3 & 3 & 0 \\
\hline Coerebidae & Coereba flaveola $(8 / 3)^{*}$ & $5(1.37)$ & 4 & 0 & 0 & 0 & 0 \\
\hline Thraupidae & Eucometis penicillata (12/10) & $35(9.62)$ & 23 & 12 & 6 & 3 & 0 \\
\hline Thraupidae & Saltator maximus $(5 / 4)$ & $24(6.59)$ & 19 & 5 & 7 & 1 & 0 \\
\hline
\end{tabular}

*One bird also infected by one male Rhipicephalus sanguineus (SZABÓ et al., 2008). 
tick species on passerine birds has been reported in São Paulo State, Brazil (LABRUNA et al., 2007). However, it should be stressed that this species has unique characteristics at the nymphal stage: scutum elongate and hypostome pointed (KEIRANS; DURDEN, 1998) and this high prevalence could be attributed to more successful identification. Nymphs of $A$. longirostre parasitize several bird species including migrating birds whereas adults are found on porcupines (Coendou spp.) (ARAGÃO, 1936; JONES et al., 1972; GUGLIELMONE et al., 2003).

Amblyomma nodosum, also a neotropical tick species is widely distributed throughout South and Central America (GUGLIELMONE et al., 2003) and was the second most numerous species found on passerine birds. Adults of this tick species parasitize anteaters (Tamandua spp. and Myrmecophaga tridactyla L.) (JONES et al., 1972), whereas subadult stages were previously reported from several passerifom bird species (LABRUNA et al., 2007; OGRZEWALSKA, 2009). It thus seems that $A$. nodosum life cycle requires a bird for feeding of immature and anteaters for adult stages. It is interesting to note that, as seen in our study, host questing $A$. nodosum ticks are seldom captured on the ground or vegetation even at places where birds carry these tick species (OGRZEWALSKA, 2009). It may suggest that sampling methods for host questing $A$. nodosum ticks are inappropriate.

Only six host-seeking ticks (five Amblyomma sp. nymphs and one $A$. nodosum adult) were captured within the forest fragment and several $R$. (B.) microplus larvae were captured at the borders. $R$. (B.) microplus larvae were maintained by regular movement of cattle near the forest. The fence surrounding this forest area prevented the access of both cattle and cattle tick. It also seems plausible to assume that birds do not carry cattle tick or are not adequate hosts for these ticks. Bearing in mind the potential environmental sites for bird infestation with ticks in the forest, the reduced number of host-seeking ticks sampled on the ground seems to be a consistent observation and higher sites should be investigated for species such as $A$. longirostre. However this reduced number of ticks in the environment is unexpected in the cerrado biome, particularly in forested phytophysiognomies where a large numbers of $A$. cajennense ticks is expected (SZABÓ et al., 2007; VERONEZ et al., 2010). Explanations for this observation are at the moment speculative but lack of primary hosts for $A$. cajennense (tapir, capybara or horse) in the fragment might explain it. It also should mention that Ogrzewalska (2009) showed that, even though it is widespread in Brazil, A. cajennense benefits from larger forest fragments with higher biodiversity, which was not the case of the site studied. It is also noteworthy that tick sampling in the environment was performed after bird capture and thus a temporal influence on our observations cannot be ruled out.

In conclusion, further tick sampling on birds as well on other animals of the Brazilian cerrado can reveal other features of tick biology in this biome. Understanding these host-parasite relationships can help understand the epidemiology of diseases and may guide conservation efforts to threatened biomes such as cerrado.

\section{Acknowledgements}

We thank the Centro Nacional de Pesquisa para Conservação de Aves Silvestres, Instituto Chico Mendes de Conservação da
Biodiversidade (CEMAVE/ICMBIO), Conselho Nacional de Desenvolvimento Científico e Tecnológico (CNPq), Fundação de Amparo à Pesquisa do Estado de Minas Gerais (FAPEMIG), Fundação de Amparo à Pesquisa do Estado de São Paulo (FAPESP), Universidade Federal de Uberlândia (UFU).

\section{References}

ARAGÃO, H. Ixodidas brasileiros e de alguns paizes limitrophes. Memórias do Instituto Oswaldo Cruz, v. 31, n. 4, p. 759-843, 1936.

ARZUA, M. et al. Amblyomma aureolatum and Ixodes auritulus (Acari: Ixodidae) on birds in southern Brazil, with notes on their ecology. Experimental and Applied Acarology, v. 31, n. 3-4, p. 283-296, 2003.

ARZUA, M.; BARROS-BATTESTI, D. M. Parasitism of Ixodes (Multidentatus) auritulus Neumann (Acari: Ixodidae) on birds from the city of Curitiba, State of Paraná, Southern Brazil. Memórias do Instituto Oswaldo Cruz, v. 94, n. 5, p. 597-603, 2003.

COMITÊ BRASILEIRO DE REGISTROS ORNITOLÓGICOS. Listas das aves do Brasil. 8. Ed. 09 ago. 2009. Disponível em: <http:// www.cbro.org.br>. Acesso em: 10 nov. 2009.

COOLEY, R. A. The genera Boophilus, Rhipicephalus and Haemaphysalis (Ixodidae) of the New World. Washington D.C.: National Institute of Health, 1946. 54 p.

GUGLiElmONE, A. A. et al. Ticks (Acari: Ixodidae) of the zoogeographic region. Atalanta, Houten, The Netherlands: International Consortium on Ticks and Tick-Borne Diseases (ICTTD-2), 2003. $173 \mathrm{p}$.

JONES, E. K. et al. The ticks of Venezuela (Acarina: Ixodidea) with a key to the species of Amblyomma in the Western hemisphere. Brigham Young University Science Bulletin. Biological Series, v. 17, p. 1-40, 1972.

KEIRANS, J. E.; DURDEN, L. A. Illustrated key to nymphs of the tick genus Amblyomma (Acari: Ixodidae) found in the United States. Journal of Medical Entomology, v. 35, n. 4, p. 489-495, 1998.

LABRUNA, M. B. Ecology of Rickettsia in South America. Annals of the New York Academy of Sciences, v. 1166, p. 156-166, 2009.

LABRUNA, M. B. et al. Ticks (Acari: Ixodidae) on wild animals from the Porto-Primavera hydroelectric power station area, Brazil. Memórias do Instituto Oswaldo Cruz, v. 97, n. 8, p. 1133-1136, 2002.

LABRUNA, M. B. et al. Ticks collected on birds in the state of São Paulo, Brazil. Experimental and Applied Acarology, v. 43, n. 2, p. 147-160, 2007.

MACHADO, L. Z. Erliquiose canina. Revista Brasileira de Parasitologia Veterinária, v. 13, Supl. 1, 2004.

MARINI, M. A. et al. Ecological correlates of ectoparasitism on Atlantic Forest birds, Brazil. Ararajuba, v. 4, n. 2, p. 93-103, 1996.

OGRZEWALSKA, M. Efeito da fragmentaçáo florestal na infestaçáo por carrapatos (Acari: Ixodidae) em aves e infecçáo de carrapatos por Rickettsia spp. no Pontal do Paranapanema, SP. 2009. 106 f. Tese (Doutorado)-Universidade de São Paulo, São Paulo, 2009.

OGRZEWALSKA, M. et al. Ticks (Acari: Ixodidae) infesting birds in an Atlantic Rain Forest region of Brazil. Journal of Medical Entomology, v. 46, n. 5, p. 1225-1229, 2009. 
OGRZEWALSKA, M. et al. Ticks (Acari: Ixodidae) infesting wild birds in an Atlantic forest area in the state of São Paulo, Brazil, with isolation of Rickettsia from the tick Amblyomma longirostre. Journal of Medical Entomology, v. 45, n. 4, p. 770-774, 2008.

OLIVEIRA-FILHO, A. T.; MARQUIS, R. J. Introduction: development of research in the Cerrados. In: OLIVEIRA, P. S.; MARQUIS, R. J. (Ed.), The Cerrados of Brazil: ecology and natural history of a Neotropical savanna. New York: Columbia University Press, 2002. p. 1-10.

OLIVEIRA-FILHO, A. T.; RATTER, J. A. Vegetation physiognomies and woody flora of the Cerrado Biome. In: OLIVEIRA, P. S.; MARQUIS, R. J. (Ed.). The Cerrados of Brazil: ecology and natural history of a Neotropical savanna. New York: Columbia University Press, 2002. p. $91-120$.

ONOFRIO, V.C. et al. Comentários e chaves para as espécies do gênero Amblyomma. In: BARROS-BATTESTI, D. M.; ARZUA, M.; BECHARA, G. H. (Ed.). Carrapatos de importância medicoveterinária da regiáo neotropical: um guia ilustrado para identificação de espécies. Sáo Paulo: Vox/ICTTD-3/Butantan, 2006a. p. 53-113.

ONOFRIO, V. C. et al. Família Ixodidae: características gerais, comentários e chave para gêneros. In: BARROS-BATTESTI, D. M.; ARZUA, M.; BECHARA, G. H. (Ed.). Carrapatos de importância medico-veterinária da regiáo neotropical: um guia ilustrado para identificação de espécies. São Paulo: Vox/ICTTD-3/Butantan, 2006b. p. 29-39.

RIDGELY, R. S.; TUDOR, G. The birds of South America, V. 1, the oscine passerines. U.K.: Oxford University Press, 1989. 516 p.

RIDGELY, R. S.; TUDOR, G. The birds of South America, V. 2, the suboscine passerines. U.K.: Oxford University Press, 1994. 814 p.

SIGRIST, T. Aves do Brasil: uma visão artística. 2. ed. Fosfértil, 2006. $672 \mathrm{p}$.

SZABÓ, M. P. J. et al. Brown dog tick Rhipicephalus sanguineus parasitizing the bird Coereba flaveola in the Brazilian Cerrado. Ciência Rural, v. 38, n. 2, p. 543-545, 2008.

SZABÓ, M. P. J.; OLEGÁRIO, M. M. M.; SANTOS, A. L. Q. Tick fauna from two locations in the Brazilian savannah. Experimental and Applied Acarology, v. 43, n. 1, p. 73-84, 2007.

VERONEZ, V. A. et al. Ticks (Acari: Ixodidae) within various phytophysiognomies of a cerrado reserve in Uberlândia, Minas Gerais, Brazil. Experimental and Applied Acarology, v. 50, n. 2, p. 169-179, 2010 . 